\section{PENEGAKAN HUKUM TERHADAP PERTAMBANGAN TANPA IZIN DI KAWASAN KAKI GUNUNG LOKON KOTA TOMOHON ${ }^{1}$}

Oleh : Ireinne T. Undap ${ }^{2}$

\begin{abstract}
ABSTRAK
Tujuan dilakukannya penelitian ini yaitu untuk mengetahui bagaimanakah upaya penegakan hukum terhadap pertambangan tanpa izin (PETI) di kawasan kaki Gunung Lokon Kota Tomohon dan bagaimanakah kendala yang dihadapi dalam upaya penegakan hukum pertambangan tanpa izin (PETI) di kawasan kaki Gunung Lokon Kota Tomohon yang dengan metode penelitian hukum normatif disimpulkan bahwa: 1. Upaya-upaya penegakan hukum terhadap pertambangan tanpa izin (PETI) di Kawasan Kaki Gunung Lokon Kota Tomohon masih belum tegas dan kurang efektif, meskipun telah menempuh berbagai cara yakni secara preventif dan secara represif. Yang pertama, upaya preventif (pencegahan) dimaksudkan sebagai usaha untuk mengadakan perubahan-perubahan yang bersifat positif terhadap kemungkinan terjadinya gangguangangguan dalam ketertiban dan keamanan (stabilitas hukum). Upaya preventif tersebut, yakni: Melakukan sosialisasi tentang perlunya izin usaha pertambangan dalam melakukan kegiatan pertambangan dan Melakukan pembinaan dan pengawasan terhadap setiap kegiatan usaha pertambangan di Kota Tomohon. Yang kedua, upaya represif (penindakan) merupakan suatu tindakan yang dilakukan oleh aparat penegak hukum sesudah terjadinya kejahatan/pelanggaran. Upaya represif tersebut, yakni: Melakukan operasi terhadap aktivitas pertambangan di lokasi pertambangan dan melakukan penyegelan terhadap kegiatan pertambangan tanpa izin. 2 . Kendala yang dialami oleh aparat penegak hukum dalam menangani pertambangan tanpa izin di Kawasan Kaki Gunung Lokon Kota Tomohon. Yang pertama, yaitu koordinasi antara aparat kepolisian, dinas energi dan sumber daya, pemerintah setempat yang masih kurang efektif. Dan kendala yang kedua, yaitu pengeluhan para pelaku usaha pertambangan
\end{abstract}

\footnotetext{
${ }^{1}$ Artikel Skripsi. Dosen Pembimbing: Dr. Jemmy Sondakh, S.H., M.H; Vecky Yanni Gosal, S.H., M.H

2 Mahassiwa pada Fakultas Hukum Unsrat, NIM.
} 16071101160 tanpa izin. Namun, untuk kendala yang kedua tentunya tidak seharusnya dijadikan alasan untuk menindak para pelaku pertambangan tanpa izin, apabila ditemukan pelangaran maka para aparat penegak hukum harus segera menindak sebagaimana yang telah diatur dan amanatkan dalam Undang-Undang yang berlaku.

Kata kunci: gunung lokon; pertambangan;

\section{PENDAHULUAN}

\section{A. Latar Belakang}

Banyaknya daerah tambang di Indonesia dan semakin maraknya kegiatan penambangan, menjadi sangat rawan akan terjadinya penambangan tanpa izin (PETI). Akibat dari adanya penambangan tanpa izin (PETI), menyebabkan timbulnya pertambangan yang berdampak buruk atau negatif terhadap lingkungan, sosial, budaya dan ekonomi.

Dampak negatif terhadap lingkungan dari pertambangan tanpa izin (PETI) tidak sejalan dengan pembangunan berkelanjutan sebagaimana yang diatur dalam UndangUndang Nomor 32 Tahun 2009 tentang Perlindungan dan Pengelolaan Lingkungan Hidup. Selain itu, pertambangan tanpa izin (PETI) tidak dapat menunjang tujuan dari pengelolaan kegiatan usaha pertambangan mineral dan batubara sebagaimana yang diatur dalam pasal 3 Undang-Undang Nomor 4 Tahun 2009 tentang Pertambangan Mineral dan Baturbara.

\section{B. Perumusan Masalah}

1. Bagaimanakah upaya penegakan hukum terhadap pertambangan tanpa izin (PETI) di kawasan kaki Gunung Lokon Kota Tomohon?

2. Bagaimanakah kendala yang dihadapi dalam upaya penegakan hukum pertambangan tanpa izin (PETI) di kawasan kaki Gunung Lokon Kota Tomohon?

\section{Metode Penelitian}

Pendekatan yang dipakai dalam penelitian skripsi ini adalah pendekatan yuridis normative.

\section{HASIL PENELITIAN DAN PEMBAHASAN}




\section{A. Upaya-Upaya Penegakan Hukum Pertambangan Tanpa Izin (PETI) di Kawasan Kaki Gunung Lokon Kota Tomohon}

Sejalan dengan kemajuan pembangunan di Kota Tomohon khususnya pembangunan sarana dan prasarana fisik serta pertumbuhan perekonomian masyarakat yang mulai lebih maju, tentunya semakin banyak membutuhkan material pembangunan berupa pasir, kerikil, dan batuan lainnya dengan jumlah yang tidak sedikit. Hal inilah yang memicu perkembangan usaha di bidang pertambangan yang tentunya akan membawa dampak positif maupun negatif terhadap lingkungan hidup, penerimaan pendapatan negara dan masyarakat sekitar. Kegiatan pertambangan di Kota Tomohon termasuk dalam pertambangan golongan mineral bukan logam dan batuan.

Kegiatan pertambangan ini dilakukan dengan memiliki izin dari pemerintah dan juga dilakukan dengan tidak memiliki izin dari pemerintah. Pada tahun 2015 di kota Tomohon, ditemukan 23 usaha tambang galian $C$ yang tidak memiliki izin pertambangan. ${ }^{3}$ Selanjutnya, pada Mei 2016 walikota Tomohon Jimmy F. Eman, S.E.Ak. dalam sambutannya yang dibacakan oleh Assisten II Ronny S. Lumowa, S.Sos., M.Si., pada saat rapat koordinasi penertiban kegiatan usaha pertambangan kota Tomohon yang dilaksanakan di aula kantor walikota, mengatakan bahwa sampai dengan tahun 2016 di kota Tomohon sudah terdapat 8 perusahaan dan juga perorangan yang telah memiliki izin resmi dari pemerintah provinsi Sulawesi Utara dalam menyelenggarakan pengelolaan kegiatan usaha pertambangan. Tetapi di sisi lain, masih terdapat juga kegiatan pertambangan yang dilakukan oleh badan usaha maupun masyarakat sekitar tanpa izin pertambangan. ${ }^{4}$ Di tahun 2017 melalui sidak yang dilakukan oleh Polres Kota Tomohon terdapat 10 pertambangan yang beroperasi dimana terdapat 7 pertambangan yang

\footnotetext{
${ }^{3}$ Ardi Kalumata, " Tomohon Kantongi 23 Usaha Tambang Galian C Tanpa Izin", di akses dari https://www.manadotoday.co.id/2015/04/2794/tomohon -kantongi-23-usaha-tambang-galian-c-tanpa-izin/ (diakses pada 2 Agustus 2019).

${ }^{4}$ Recky Pelealu, "Masih Ada Usaha Pertambangan di Tomohon yang Tak Kantongi Izin", diakses dari https://beritamanado.com/masih-ada-usahapertambangan-di-tomohon-yang-tak-kantongi-izin/ (diakses pada 2 Agustus 2019).
}

memiliki izin, dan 3 pertambangan tidak memiliki izin. ${ }^{5}$ Di tahun 2019 berdasarkan wawancara bersama IPDA Desnaldi Butarbutar Kepala Unit 5 Tindak Pidana Tertentu Polres Kota Tomohon mengatakan bahwa "Jumlah tambang batuan yang beroperasi di wilayah Kakaskasen ada sekitar 10 tambang dan berdasarkan sidak yang kami lakukan beberapa bulan lalu baru 1 perusahaan yang mempunyai izin pertambangan". ${ }^{6}$ Berikut tabel daftar penambang yang melakukan kegiatan pertambangan di Kota Tomohon: ${ }^{7}$

Tabel 2

Daftar Penambang yang Melakukan Kegitan

\begin{tabular}{|c|c|c|c|}
\hline \multicolumn{4}{|c|}{ Pertambangan } \\
\hline No & NAMA & LOKASI & KOMODITAS \\
\hline 1. & $\begin{array}{l}\text { PT. Cahaya } \\
\text { Abadi Lestari }\end{array}$ & $\begin{array}{l}\text { Kel. } \\
\text { Kakaskasen I, } \\
\text { Kec. Tomohon } \\
\text { Utara }\end{array}$ & Batuan \\
\hline 2. & $\begin{array}{l}\text { PT. Dayana } \\
\text { Cipta }\end{array}$ & $\begin{array}{l}\text { Kel. } \\
\text { Kakaskasen I, } \\
\text { Kec. Tomohon } \\
\text { Utara }\end{array}$ & Batuan \\
\hline 3. & $\begin{array}{l}\text { PT. Sekar Jaya } \\
\text { Esa }\end{array}$ & $\begin{array}{l}\text { Kel. } \\
\text { Kakaskasen II, } \\
\text { Kec. Tomohon } \\
\text { Utara }\end{array}$ & Batuan \\
\hline 4. & $\begin{array}{l}\text { CV. Central } \\
\text { Gemilang }\end{array}$ & $\begin{array}{l}\text { Kinilow I, Kec. } \\
\text { Tomohon } \\
\text { Utara }\end{array}$ & Batuan \\
\hline 5. & $\begin{array}{l}\text { CV. Kasih } \\
\text { Sayang }\end{array}$ & $\begin{array}{l}\text { Kel. } \\
\text { Kakaskasen I, } \\
\text { Kec. Tomohon } \\
\text { Utara }\end{array}$ & Batuan \\
\hline 6. & $\begin{array}{l}\text { CV. Cahaya } \\
\text { Miracle }\end{array}$ & $\begin{array}{l}\text { Kel. } \\
\text { Kakaskasen I, } \\
\text { Kec. Tomohon } \\
\text { Utara }\end{array}$ & Batuan \\
\hline 7. & $\begin{array}{l}\text { Budiman } \\
\text { Limpo }\end{array}$ & $\begin{array}{l}\text { Kinilow I, Kec. } \\
\text { Tomohon } \\
\text { Utara }\end{array}$ & Batuan \\
\hline 8. & $\begin{array}{l}\text { PT. Lokon } \\
\text { Sarana Mandiri }\end{array}$ & $\begin{array}{l}\text { Kel. } \\
\text { Kakaskasen I, } \\
\text { Kec. Tomohon } \\
\text { Utara }\end{array}$ & Batuan \\
\hline 9. & $\begin{array}{l}\text { PT. Marga } \\
\text { Dwitaguna }\end{array}$ & $\begin{array}{l}\text { Kel. } \\
\text { Kakaskasen I, } \\
\text { Kec. Tomohon } \\
\text { Utara }\end{array}$ & Batuan \\
\hline
\end{tabular}

Dari data yang di dapatkan dari Dinas Energi dan Sumber Daya Mineral, dari 9 perusahaan tersebut, yang melaksanakan kegitan pertambangan dengan mempunyai izin pertambangan hanya 2 perusahaan. Kegiatan pertambangan ini sebagian besar dilakukan

\footnotetext{
5 Staff Dailymanado, Polres Sidak Galian C, http://www.dailymanado.com/2017/02/04/polres-sidakgalian-c-l, (diakses pada 2 agustus 2019)

6 Desnaldi Butarbutar, Kepala Unit 5 Reskrim Tindak Pidana Tertentu Polres Kota Tomohon, Wawancara, 28 Oktober 2019.

7Dinas ESDM Prov.Sulut, Data Penambang yang Melakukan Kegiatan Pertambangan, 2019
} 
dengan tanpa memiliki izin usaha pertambangan operasi produksi.

Setiap orang yang akan melakukan kegiatan usaha pertambangan harus mendapatkan izin dari pejabat yang berwenang. Tanpa adanya izin tersebut, maka orang yang melakukan usaha pertambangan tersebut dapat di kualifikasi sebagai penambang tidak sah (illegal mining). Konsekuensi dari orang yang melakukan usaha pertambangan tanpa izin dapat dipidana. Dalam Pasal 158 UndangUndang Nomor 4 Tahun 2009 tentang Pertambangan Mineral dan Batubara telah ditentukan lima pasal yang dilanggar oleh orang yang melakukan usaha pertambangan tanpa izin. ${ }^{8}$ Kelima pasal itu, meliputi :

a. Pasal 37 mengatur tentang kewenangan pejabat dalam pemberian IUP;

b. Pasal 40 ayat (3) mengatur tentang kewajiban pemegang IUP yang akan mengusahakan mineral lain, selain yang telah ditentukan dalam IUPnya;

c. Pasal 48 tentang IUP Operasi Produksi;

d. Pasal 67 ayat (1) atau ayat (5) mengatur tentang kewenangan menteri dalam memberikan IUPK atau pemegang IUPK yang menyatakan tidak berminat untuk mengusahakan mineral lain yang ditemukan tersebut.

Berdasarkan data dari Dinas Energi dan Sumber Daya Mineral Provinsi Sulawesi Utara hanya dua perusahaan yang memiliki IUP Operasi Produksi. Kedua perusahaan tersebut dapat dilihat pada tabel di bawah ini: ${ }^{9}$

Tabel 3

Daftar Perusahaan yang Memiliki IUP Operasi Produksi

\begin{tabular}{|c|l|c|c|}
\hline No. & \multicolumn{1}{|c|}{$\begin{array}{c}\text { Nama } \\
\text { Perusahaan }\end{array}$} & Luas (ha) & Tahap Kegiatan \\
\hline 1. & $\begin{array}{l}\text { PT. Sekar Jaya } \\
\text { Esa }\end{array}$ & 5,64 ha & Operasi Produksi \\
\hline 2. & $\begin{array}{l}\text { PT. Lokon } \\
\text { Sarana Mandiri }\end{array}$ & 6,4 ha & $\begin{array}{c}\text { Operasi Produksi } \\
\text { Khusus } \\
\text { Pengolahan dan } \\
\text { Pemurnian }\end{array}$ \\
\hline
\end{tabular}

Berdasarkan hasil wawancara dengan Staff Bidang Mineral dan Batubara Dinas Energi dan Sumber Daya Mineral Provinsi Sulawesi Utara,

${ }^{8}$ Salim HS, Hukum Pertambangan Mineral dan Batubara, Op.cit., hlm 299-300.

${ }^{9}$ Dinas ESDM Prov.Sulut, Data Perusahaan yang Memiliki IUP Operasi Produksi, 2019
Bapak Donie Boyoh, mengatakan bahwa "Baru dua perusahaan pertambangan batuan di Kota Tomohon yang izinnya sudah pada tahap kegiatan operasi produksi, bukannya perusahaan lainnya tidak mengurus izin pertambangan, mereka sudah melakukan pengurusan izin hanya saja prosesnya, ada yang baru sampai pada WIUP dan ada juga yang pada tahap eksplorasi. Apabila melakukan kegiatan pertambangan sebelum mempunyai IUP Operasi Produksi itu dianggap tindakan illegal yang bertentangan dengan ketentuan peraturan perundang-undangan".

Berikut tabel perusahaan yang melakukan kegiatan pertambangan tanpa adanya IUP Operasi Produksi: ${ }^{10}$

Tabel 4

Perusahaan yang Melakukan Kegitan Pertambangan Tanpa IUP Operasi Produksi

\begin{tabular}{|c|l|r|c|}
\hline No. & \multicolumn{1}{|c|}{$\begin{array}{c}\text { Nama } \\
\text { Perusahaan }\end{array}$} & Luas (ha) & Tahap Kegiatan \\
\hline 1. & $\begin{array}{l}\text { PT. Cahaya } \\
\text { Abadi Lestari }\end{array}$ & 4,80 ha & Eksplorasi \\
\hline 2. & $\begin{array}{l}\text { PT. Dayana } \\
\text { Cipta }\end{array}$ & 12,68 ha & Eksplorasi \\
\hline 3. & $\begin{array}{l}\text { CV. Central } \\
\text { Gemilang }\end{array}$ & 9,45 ha & Eksplorasi \\
\hline 4. & $\begin{array}{l}\text { CV. Cahaya } \\
\text { Miracle }\end{array}$ & 2,55 ha & Eksplorasi \\
\hline 5. & $\begin{array}{l}\text { CV. Kasih } \\
\text { Sayang }\end{array}$ & 5,1 ha & WIUP \\
\hline 6. & Budiman Limpo & 5,00 ha & WIUP \\
\hline 7. & $\begin{array}{l}\text { PT. Marga } \\
\text { Dwitaguna }\end{array}$ & & terSebUt \\
\hline
\end{tabular}

Perusahaan-perusahan tersebut belum memiliki IUP Operasi Produksi. Namun, mereka telah melakukan kegiatan pertambangan dan hal tersebut bertentangan dengan ketentuan perundang-undangan yang berlaku dan dapat dipidana karenanya. Ketentuan pidana terhadap kejahatan pertambangan tanpa izin / illegal mining yang dilakukan oleh perusahaanperusahaan tersebut diatur Peraturan Daerah Provinsi Sulawesi Utara Nomor 3 Tahun 2019 Tentang Pertambangan Mineral, yang terdapat dalam Pasal 74, yang menyatakan bahwa: ${ }^{11}$ "Setiap orang dan/atau badan usaha dilarang:

a. Melakukan kegiatan pertambangan mineral tanpa izin kecuali yang

${ }^{10}$ Dinas ESDM Prov.Sulut, Data Perusahaan yang

Melakukan Kegitan Pertambangan Tanpa IUP Operasi

Produksi, 2019

11 Pasal 74, Perda Provinsi Sulawesi Utara Nomor 3 Tahun 2019 Tentang Pertambangan Mineral. 
diamanatkan pada pasal 22 UndangUndang Nomor 4 Tahun 2009; dan

b. Melakukan pengelolahan dan pemurnian dan/atau pengangkutan dan penjualan dari hasil penambangan yang tidak memiliki IUP, IPR, IUPK."

Dan selanjutnya diatur dengan jelas dalam Undang-Undang Nomor 4 Tahun 2009 tentang Pertambangan Mineral dan Batubara, yang diatur dalam Pasal 158 dan Pasal 160 ayat (1) dan (2). Masing-masing pasal tersebut berbunyi: ${ }^{12}$

Pasal 158 menegaskan bahwa :

"Setiap orang yang melakukan usaha penambangan tanpa IUP, IPR atau IUPK sebagaimana yang dimaksud dalam Pasal 37, Pasal 40 ayat (3), Pasal 48, Pasal 67 ayat (1), Pasal 74 ayat (1) atau ayat (5) dipidana dengan pidana penjara paling lama 10 (sepuluh) tahun dan denda paling banyak Rp. 10.000.000.000,00 (sepuluh miliar rupiah)."

Pasal 160 :

Ayat (1): "Setiap orang yang melakukan eksplorasi tanpa memiliki IUP atau IUPK sebagaimana dimaksud dalam pasal 37 atau pasal 74 ayat (1) dipidana dengan pidana kurungan paling lama 1 (satu) tahun atau denda paling banyak $\mathrm{Rp}$. 200.000.000,00 (dua ratus juta rupiah)."

Ayat (2): "Setiap orang yang mempunyai IUP Eksplorasi tetapi melakukan kegiatan operasi produksi dipidana penjara paling lama 5 (lima) tahun dan denda paling banyak $\mathrm{Rp}$. 10.000.000.000,00 (sepuluh miliar rupiah)."

Meskipun telah diatur secara tegas didalam undang-undang tetap saja para penambang melakukan kegiatan pertambangan tanpa izin (PETI). Kejahatan pertambangan tanpa izin harus mendapat perhatian serius dari pihak aparat kepolisian, mengingat tugas dari Dinas Energi dan Sumber Daya Mineral hanya sebatas melakukan pengawasan. Sedangkan yang melakukan penindakan adalah aparat kepolisian. Oleh karenanya diperlukan upayaupaya penegakan hukum yang dilakukan oleh

12 Pasal 158 dan 160 ayat (1) dan (2) Undang-Undang Nomor 4 Tahun 2009 Tentang Pertambangan Mineral dan Batubara aparat kepolisian bersama dengan dinas terkait. Berdasarkan penuturan Kepala Unit 5 Tindak Pidana Tertentu Polres Tomohon, IPDA Desnaldi Butarbutar, terkait upaya-upaya penegakan hukum yang dilakukan oleh kepolisian terhadap pertambangan tanpa izin (PETI) di Kota Tomohon, yakni :13

1. Kepolisian melakukan sosialisasi tentang perlunya izin usaha pertambangan dalam melakukan kegiatan pertambangan serta ketentuan pidana apabila tidak memiliki izin usaha pertambangan;

2. Melakukan operasi/sidak terhadap aktivitas pertambangan di lokasi pertambangan;

3. Melakukan penyegelan terhadap kegiatan pertambangan tanpa izin;

Selain itu, berdasarkan wawancara bersama Kepala Kepolisian Sektor Tomohon Utara, AKP Ronny Rondonuwu, mengatakan bahwa "Upaya-upaya yang kami lakukan yakni berkoordinasi dengan pihak pemerintah kecamatan, bahkan dalam setiap rapat koordinasi forum pimpinan kecamatan selalu diangkat agar supaya memberi himbauan kepada masyarakat, kiranya dalam melaksanakan kegiatan pertambangan dapat melaksanakan pengurusan izin sebagaimana perintah undang-undang." ${ }^{14}$

Lebih lanjut, upaya yang dilakukan oleh Dinas Energi dan Sumber Daya Mineral Provinsi Sulawesi Utara, berdasarkan wawancara bersama Staff Bidang Mineral dan Batubara Dinas ESDM Sulawesi Utara, Bapak Donie Boyoh, mengatakan bahwa "Dinas hanya melakukan pembinaan dan pengawasan yang dilakukan oleh Inspektur Tambang dari kementerian yang ada di Sulawesi Utara, selain itu juga dinas melakukan koordinasi bersama pihak kepolisian dan dinas lingkungan hidup dalam tim khusus yakni Tim Terpadu yang bekerja sama dengan pemerintah setempat." ${ }^{15}$

Upaya-upaya aparat penegak hukum dan dinas terkait mengenai penegakan hukum terhadap pertambangan tanpa izin (PETI) di

13 Desnaldi Butarbutar, Kepala Unit 5 Reskrim Tindak Pidana Tertentu Polres Kota Tomohon, Wawancara, 28 Oktober 2019.

\footnotetext{
${ }^{14}$ Ronny Rondonuwu, Kepala Kepolisian Sektor Tomohon Utara, Wawancara, 4 Oktober 2019

15 Donie Boyoh, Staff Bidang Mineral dan Batubara Dinas ESDM Sulawesi Utara, Wawancara, 29 Oktober 2019
} 
Kawasan Kaki Gunung Lokon Kota Tomohon telah menempuh berbagai cara yakni secara preventif dan secara represif. Dalam hal ini, penulis menggolongkan upaya-upaya tersebut, yakni sebagai berikut :

1. Upaya Preventif Upaya preventif (pencegahan) dimaksudkan sebagai usaha untuk mengadakan perubahan-perubahan yang bersifat positif terhadap kemungkinan terjadinya gangguan-gangguan dalam ketertiban dan keamanan (stabilitas hukum). Upaya preventif tersebut, yakni:
a. Melakukan sosialisasi tentang perlunya izin usaha pertambangan dalam melakukan kegiatan pertambangan.
b. Melakukan pembinaan dan pengawasan terhadap setiap kegiatan usaha pertambangan di Kota Tomohon.

2. Upaya Represif Upaya represif (penindakan) merupakan suatu tindakan yang dilakukan oleh aparat penegak hukum sesudah terjadinya kejahatan/pelanggaran. Upaya represif tersebut, yakni:

a. Melakukan operasi terhadap aktivitas pertambangan di lokasi pertambangan;

b. Melakukan penyegelan terhadap kegiatan pertambangan tanpa izin.

Namun, upaya-upaya tersebut masih belum terlaksana dengan baik dikarenakan adanya kendala-kendala yang dihadapi oleh para aparat penegak hokum

\section{B. Kendala-Kendala dalam Upaya Penegakan Hukum Pertambangan Tanpa Izin (PETI) di Kawasan Kaki Gunung Lokon Kota Tomohon}

Dalam melaksanakan upaya-upaya penegakan hukum aparat kepolisian dan pemerintah mengalami kendala-kendala yang membuat terhambatnya proses penegakan hukum. Adapun beberapa kendala yang dialami oleh aparat penegak hukum dalam menangani pertambangan tanpa izin di Kawasan Kaki Gunung Lokon Kota Tomohon, yakni :

1. Koordinasi antara Aparat Kepolisian, Dinas Energi dan Sumber Daya, Pemerintah
Setempat, dan Pihak Terkait Lainnya yang Masih Kurang Efektif

Koordinasi antara aparat kepolisian bersama dengan pihak-pihak terkait yang masih kurang efektif dapat mempengaruhi penegakan hukum yang dijalankan, karena dalam melakukan penyidikan diperlukan bukti-bukti surat izin usaha pertambangan yang sah dan diperlukan keterangan dari saksi ahli dalam melaksanakan penyidikan terhadap pertambangan tanpa izin. Apabila koordinasi ini tidak berjalan efektif maka dapat menghambat proses penyidikan. Hal ini juga disampaikan oleh Kepala Kepolisian Sektor Tomohon Utara, AKP Ronny Rondonuwu, yang mengatakan bahwa "Kendala yang kami hadapi yaitu menyangkut kurangnya koordinasi antara kami dengan pihak-pihak terkait. Memang sudah ada koordinasi dengan pihak lainnya namun, koordinasi tersebut masih kurang efektif. Padahal dalam melakukan upaya penegakan hukum kami membutuhkan keterangan para ahli dalam hal ini, berasal dari pihak dinas-dinas terkait." ${ }^{\prime 16}$

Koordinasi yang masih kurang efektif ini juga membuat tidak adanya keseragaman data yang dimiliki antara aparat kepolisian dan dinas ESDM Provinsi Sulawesi Utara. Berdasarkan wawancara bersama IPDA Desnaldi Butarbutar Kepala Unit 5 Tindak Pidana Tertentu Polres Kota Tomohon mengatakan bahwa "Jumlah tambang batuan yang beroperasi di wilayah Kakaskasen ada sekitar 10 tambang dan berdasarkan sidak yang kami lakukan beberapa bulan lalu baru 1 perusahaan yang mempunyai izin pertambangan". ${ }^{17} \mathrm{Hal}$ ini berbeda dengan data yang dimiliki oleh dinas ESDM Provinsi Sulawesi Utara, dimana berdasarkan data yang diberikan terdapat 9 perusahaan yang beroperasi dan hanya 2 diantaranya yang memiliki IUP Operasi Produksi.

Koordinasi ini dibutuhkan agar terjadi keseragaman data antara aparat kepolisian dan pihak-pihak terkait serta pihak kepolisian bisa mengklarifikasi langsung kepada para ahli dibidangnya untuk memastikan tentang ada atau tidaknya suatu surat izin usaha pertambangan agar para pelaku pertambangan

\footnotetext{
${ }^{16}$ Ronny Rondonuwu, Kepala Kepolisian Sektor Tomohon Utara, Wawancara, 4 Oktober 2019

17 Desnaldi Butarbutar, Kepala Unit 5 Reskrim Tindak Pidana Tertentu Polres Tomohon, Wawancara, 28 Oktober 2019
} 
tidak lagi mengelak dari perbuatan pidana yang mereka lakukan.

2. Pengeluhan Para Pelaku Usaha Pertambangan Tanpa Izin

Berdasarkan hasil wawancara ditemukan bahwa pengeluhan para pelaku usaha pertambangan tanpa izin menjadi salah satu kendala dalam melaksanakan penegakan hukum. Berdasarkan wawancara pada Kepala Unit 5 Tindak Pidana Tertentu Polres Kota Tomohon, IPDA Desnaldi Butarbutar mengatakan bahwa "Kendala yang kami dapati saat melakukan upaya penegakan hukum di lokasi pertambangan sebenarnya adalah pengeluhan dari para pelaku usaha pertambangan tanpa izin. Banyak dari mereka yang mengatakan bahwa jika tambang ini ditutup bagaimana kami bisa menghidupi keluarga kami? Dimana kami mau mencari nafkah jika tambang ini ditutup?. Pengeluhan seperti ini yang membuat kami pihak kepolisian merasa ragu untuk melakukan penindakan dan hanya mengingatkan serta mensosialisasikan tentang perlunya izin dalam melakukan kegiatan pertambangan. Bukannya kami pihak kepolisian tidak mampu untuk melakukan penindakan, tetapi karena rasa kemanusiaan terhadap mereka." ${ }^{\prime 18}$

Dikarenakan pengeluhan dari pelaku pertambangan tanpa izin maka upaya penegakan hukum yang dilakukan oleh pihak kepolisian yang sebelumnya datang dengan tujuan untuk melakukan upaya represif berupa menertibkan dan menindak tegas para pelaku pertambangan tanpa izin menjadi terhambat dan hanya melakukan upaya preventif dengan mengingatkan dan mensosialisasikan kembali tentang perlunya izin usaha pertambangan.

Kepala Unit 5 Tindak Pidana Tertentu Polres Kota Tomohon, IPDA Desnaldi Butarbutar juga mengatakan bahwa "Saat kami menyambangi lokasi pertambangan para pelaku usaha pertambangan selalu beralasan bahwa mereka telah melakukan pengurusan izin. Namun, sebenarnya apabila belum mempunyai izin, tambang tersebut dapat kami tutup. Tetapi para pengusaha mengatakan bahwa mereka telah membayar pajak dan untuk izin, mereka

${ }^{18}$ Desnaldi Butarbutar, Kepala Unit 5 Reskrim Tindak Pidana Tertentu Polres Kota Tomohon, Wawancara, 28 Oktober 2019. mengatakan bahwa dari pihak provinsi yang lama dalam mengeluarkan izin. Jadi, kami mengatakan untuk segera mempercepat proses pengurusan izin agar kegiatan pertambangan dapat dilakukan dengan mengantongi izin.." ${ }^{\prime 19}$

\section{PENUTUP}

\section{A. Kesimpulan}

1. Upaya-upaya penegakan hukum terhadap pertambangan tanpa izin (PETI) di Kawasan Kaki Gunung Lokon Kota Tomohon masih belum tegas dan kurang efektif, meskipun telah menempuh berbagai cara yakni secara preventif dan secara represif. Yang pertama, upaya preventif (pencegahan) dimaksudkan sebagai usaha untuk mengadakan perubahan-perubahan yang bersifat positif terhadap kemungkinan terjadinya gangguan-gangguan dalam ketertiban dan keamanan (stabilitas hukum). Upaya preventif tersebut, yakni: Melakukan sosialisasi tentang perlunya izin usaha pertambangan dalam melakukan kegiatan pertambangan dan Melakukan pembinaan dan pengawasan terhadap setiap kegiatan usaha pertambangan di Kota Tomohon. Yang kedua, upaya represif (penindakan) merupakan suatu tindakan yang dilakukan oleh aparat penegak hukum sesudah terjadinya kejahatan/pelanggaran. Upaya represif tersebut, yakni: Melakukan operasi terhadap aktivitas pertambangan di lokasi pertambangan dan melakukan penyegelan terhadap kegiatan pertambangan tanpa izin.

2. Kendala yang dialami oleh aparat penegak hukum dalam menangani pertambangan tanpa izin di Kawasan Kaki Gunung Lokon Kota Tomohon. Yang pertama, yaitu koordinasi antara aparat kepolisian, dinas energi dan sumber daya, pemerintah setempat yang masih kurang efektif. Dan kendala yang kedua, yaitu pengeluhan para pelaku usaha pertambangan tanpa izin. Namun, untuk kendala yang kedua tentunya tidak seharusnya dijadikan alasan untuk menindak para pelaku pertambangan tanpa izin, apabila ditemukan pelangaran 
maka para aparat penegak hukum harus segera menindak sebagaimana yang telah diatur dan amanatkan dalam Undang-Undang yang berlaku.

\section{B. Saran}

Sehubungan dengan pertambangan tanpa izin yang terjadi di Kawasan Kaki Gunung Lokon Kota Tomohon. Penulis berharap pemerintah serta aparat penegak hukum dan pihak terkait lainnya untuk lebih meningkatkan kerjasama dan koordinasi antar para pihak agar upaya penegakan hukum terhadap pertambangan tanpa izin di Kota Tomohon dapat berjalan dengan sebagaimana mestinya. Selain itu diharapkan juga untuk semakin tegas menindak para pelaku penambang tanpa izin dan tidak menjadikan pengeluhan masyarakat menjadi alasan untuk tidak menindak para pelaku penambang tanpa izin. Apabila ditemukan harus ditindak sebagaimana yang diatur dalam undang-undang.

\section{DAFTAR PUSTAKA}

Efendi A'an, Hukum Lingkungan, Citra Aditya Bakti, Jakarta, 2014.

Gunadi Ismu dan Jonaedi Efendi, Cepat dan Mudah Memahami Hukum Pidana, Kencana, Jakarta, 2014.

HS Salim, Hukum Pertambangan di Indonesia, Cetakan ke-7, Rajawali Pers, Jakarta, 2014.

Hukum Pertambangan Mineral dan Batubara, Sinar Grafika, Jakarta, 2014.

Prasetyo Teguh, Hukum Pidana, Rajawali Pers, Jakarta, 2014.

Redi Ahmad, Hukum Penyelesaian Sengketa Pertambangan Mineral dan Batubara, Sinar Grafika, Jakarta, 2017.

Siahaan N.H.T., Hukum Lingkungan dan Ekologi Pembangunan, Edisi Kedua, Erlangga, Jakarta, 2004.

Sutedi Adrian, Hukum Pertambangan, Sinar Grafika, Jakarta, 2012.

Tim Prima Pena, Kamus Besar Bahasa Indonesia, Gitamedia Press.

Waluyo Bambang, Penelitian Hukum Dalam Praktek, Sinar Grafika, Jakarta, 2002.

\section{Peraturan Perundang-Undangan}

Kitab Undang-Undang Hukum Acara Pidana
Undang-Undang Dasar Negara Republik Indonesia Tahun 1945.

Undang-Undang Nomor 23 Tahun 2014 Tentang Pemerintah Daerah

Undang-Undang Nomor 32 Tahun 2009 tentang Perlindungan dan Pengelolaan Lingkungan Hidup

Undang-Undang Nomor 4 tahun 2009 tentang Pertambangan Mineral dan Batubara

Peraturan Daerah Provinsi Sulawesi Utara Nomor 3 Tahun 2019 tentang Pertambangan Mineral

\section{Website}

Asshiddiqie Jimly, Penegakan Hukum, https://www.google.com/url?sa=t\&sou rce=web\&url=http://www.jimly.com/m akalah/namafile/56/penegakan_hukum .pdf//, (diakses pada 10 September 2019).

Dailymanado Staff, Polres Sidak Galian C, http://www.dailymanado.com/2017/02 104/polres-sidak-galian-c-/, (diakses pada 2 agustus 2019).

Kalumata Ardi, "Tomohon Kantongi 23 Usaha Tambang Galian C Tanpa Izin", di akses dari

https://www.manadotoday.co.id/2015/ 04/2794/tomohon-kantongi-23-usahatambang-galian-c-tanpa-izin/ , (diakses pada 2 Agustus 2019).

Mulyana Ridwan Nanda, "KLHK: Terindikasi Pertambangan llegal, Negara Rugi Lebih Dari Rp 38 Triliun per Tahun", di akses dari

https://nasional.kontan.co.id/news/klh k-terindikasi-pertambangan-ilegalnegara-rugi-lebih-dari-rp-38-triliun-pertahun (diakses pada 2 Agustus 2019).

Pelealu Recky, "Masih Ada Usaha Pertambangan di Tomohon yang Tak Kantongi Izin", diakses dari https://beritamanado.com/masih-adausaha-pertambangan-di-tomohonyang-tak-kantongi-izin/ (diakses pada 2 Agustus 2019).

\section{Sumber Lain}

Boyoh Donie, Staff Bidang Mineral dan Batubara Dinas ESDM Sulawesi Utara, Wawancara, 29 Oktober 2019 
Butarbutar Desnaldi, Kepala Unit 5 Reskrim Tindak Pidana Tertentu Polres Kota Tomohon, Wawancara, 28 Oktober 2019.

Ronny Rondonuwu, Kepala Kepolisian Sektor Tomohon Utara, Wawancara, 4 Oktober 2019.

Dinas ESDM Prov.Sulut, Data Penambang yang Melakukan Kegiatan Pertambangan, 2019

Dinas ESDM Prov.Sulut, Data Perusahaan yang Melakukan Kegiatan Pertambangan Tanpa IUP Operasi Produksi, 2019

Dinas ESDM Prov.Sulut, Data Perusahaan yang Memiliki IUP Operasi Produksi, 2019. 